\title{
Attention should be paid to the "cases to be checked" in the screening of COVID-19
}

\author{
Guifang Yang ${ }^{1,2}$, Wen Peng ${ }^{1,2}$, Yang Zhou ${ }^{1,2}$, Yuzhong Cai ${ }^{1,2}$, Ning Ding ${ }^{1,2}$, Xiangping Chai ${ }^{1,2}$ \\ ${ }^{1}$ Department of Emergency Medicine, The Second Xiangya Hospital, ${ }^{2}$ Emergency Medicine and Difficult Diseases Institute, Central South \\ University, Changsha, China \\ Correspondence to: Xiangping Chai. Department of Emergency Medicine, the Second Xiangya Hospital, Central South University, 139 Renmin Road, \\ Changsha 410011, China. Email: chaixiangping@csu.edu.cn.
}

Received: 25 March 2020; Accepted: 02 June 2020; Published: 25 June 2020.

doi: 10.21037/jhmhp-20-42

View this article at: http://dx.doi.org/10.21037/jhmhp-20-42

Several patients with viral pneumonia in December 2019 were identified to be related to the Huanan seafood market in Wuhan, China $(1,2)$. The virus, severe acute respiratory syndrome coronavirus 2 (SARS-CoV-2), has spread so fast that it has swept the whole of China and some other countries in the world (3). The Chinese government of the national health commission has formed and formulated the diagnosis and treatment plan of the 2019 novel coronavirus disease (COVID-19). So far, it has been updated to the fifth edition, which divided the screening of COVID-19 pneumonia into two parts: suspected cases and confirmed cases (4). However, in the clinical practice of the COVID-19 screening, we found that there were some perplexities. A few patients did not meet the standard of suspected cases but they have some problems in epidemiological history, clinical symptoms or imaging examination so that physicians were afraid of letting them go home or admitting them to the hospitalization in general ward. In view of this situation, we defined this kind of patients as "cases to be checked", and established a screening process.

\section{The screening process of the "cases to be checked" in fever clinic}

Patients in the fever clinic were divided into four categories. The first was the patients who can be excluded SARS-CoV-2 infection. The second was the cases to be checked. The third was the suspected SARS-CoV-2 infection patients. The fourth was confirmed patients with COVID-19. The category of "cases to be checked" was divided into general patients and critical patients, and the two parts of patients were isolated respectively. The general patients were arranged individually in the ordinary quarantine screening room, and the critical patients were arranged in the isolation ward with first aid equipment. The virus nucleic acid tests were carried out in these patients and if the result was negative, the test will be done again. If the two test results were negative, the isolation will be released and the patient will enter the normal medical treatment process. If positive, they will be treated in accordance with the confirmed patient treatment process. Before the patients to be checked were released quarantine, their companions were also regarded as cases to be checked.

\section{The screening process of the "cases to be checked" in patients needed to be hospitalization}

Suspected and confirmed patients should be admitted to designated quarantine hospitals, except for patients who need emergency surgery or pregnant women who were about to give birth. However, some of the "cases to be checked" were admitted to the general ward. In view of this situation, our hospital requires each department to keep one or two relatively independent rooms for screening and isolation of these patients and special health care personnel were needed to take care of these patients in order to minimize the number of medical staff exposed to the same patient.

As of February 16, 2020, initial screening was offered to a total of 1,567 patients in the fever clinic, in which 31 cases were confirmed SARS-CoV-2 infection and 132 cases were 
suspected. Meanwhile, 76 cases were listed as "cases to be checked", in which four patients were identified COVID-19 at last.

We found that if we only screening COVID-19 pneumonia in suspected cases, we can not make sure that all of these infected patients were identified, for there were also some SARS-CoV-2 infected patients hidden in the "cases to be checked". So, we should pay attention to the population with a large base of "cases to be checked" in order to avoid missed diagnoses. In addition, it is of great clinical significance to set up a reasonable screening process for the "cases to be checked".

\section{Acknowledgments}

Funding: This work was supported by Special Emergency Treatment for Novel Coronavirus Pneumonia, Science and Technology Projects of Hunan province, China (2020SK3004 to XC).

\section{Footnote}

Provenance and Peer Review: This article was a standard submission to the journal. The article was sent for external peer review.

Conflicts of Interest: All authors have completed the ICMJE uniform disclosure form (available at http://dx.doi. org/10.21037/jhmhp-20-42). The authors have no conflicts of interest to declare.

Ethical Statement: The authors are accountable for all aspects of the work in ensuring that questions related

doi: 10.21037/jhmhp-20-42

Cite this article as: Yang G, Peng W, Zhou Y, Cai Y, Ding N, Chai X. Attention should be paid to the "cases to be checked" in the screening of COVID-19. J Hosp Manag Health Policy 2020;4:11. to the accuracy or integrity of any part of the work are appropriately investigated and resolved.

Open Access Statement: This is an Open Access article distributed in accordance with the Creative Commons Attribution-NonCommercial-NoDerivs 4.0 International License (CC BY-NC-ND 4.0), which permits the noncommercial replication and distribution of the article with the strict proviso that no changes or edits are made and the original work is properly cited (including links to both the formal publication through the relevant DOI and the license). See: https://creativecommons.org/licenses/by-nc-nd/4.0/.

\section{References}

1. Huang C, Wang Y, Li X, et al. Clinical features of patients infected with 2019 novel coronavirus in Wuhan, China. Lancet 2020;395:497-506.

2. Chen N, Zhou M, Dong X, et al. Epidemiological and clinical characteristics of 99 cases of 2019 novel coronavirus pneumonia in Wuhan, China: a descriptive study. Lancet 2020;395:507-13.

3. World Health Organization. Novel coronavirus (2019$\mathrm{nCoV}$ ) situation report-27. Published on February 16, 2020. Available online: https://www.who.int/docs/defaultsource/coronaviruse/situation-reports/20200216-sitrep27-covid-19.pdf?sfvrsn=78c0eb78_2

4. China National Health Commission. The diagnosis and treatment plan of the 2019 novel coronavirus disease. Published on February 8, 2020. (in Chinese). Available online: http://www.gov.cn/zhengce/ zhengceku/2020-02/09/5476407/files/765d1e65b7d14430 $81053 \mathrm{c} 29 \mathrm{ad} 37 \mathrm{fb} 07 . \mathrm{pdf}$ 